\title{
Capturing the dual role of female medical workers during the COVID-19 pandemic in Surabaya
}

\author{
D.W. Apriadi*, D. Mawarni \& M. Saputra \\ Universitas Negeri Malang, Malang City, Indonesia
}

\begin{abstract}
The aim of this study is to see the dual role of female medical worker in the family and how it has changed since the outbreak of the COVID-19 pandemic, as well as to see the views of female medical workers on the culture of the domestic realm. This research is a qualitative with purposive sampling technique. Data collection techniques used participatory observation, in-depth interviews conducted via video calls and or telephone, and supported by the literature reviews. The results showed that has led to changes in the division of duties in the domestic realm, particularly for medical personnel handling COVID-19 at their hospitals. Based on the analysis, it was found that the view of the cultural concept of the domestic realm is that the responsibility of the wife is more determined by the family where religion is the dominant factor affecting this view.
\end{abstract}

Keywords: patriarchy culture, dual role, female medical workers, COVID-19 Pandemic

\section{INTRODUCTION}

Women have a role in reproduction, productive economy, and community management (Zuhdi 2019). This means that women have a dual role as housewives/wives who have to do household chores and also as breadwinners to help the family economy. However, the general opinion of the community is that a woman or a mother is considered taboo or violates her nature as a woman if she is too often outside the home (Arsini 2014).Women are considered to have only three functions, namely cooking, bearing children, decorating, or only having kitchen duties, wells and mattresses (Arifin in (Rostiyati 2018). McLellan and Uys, in 2009, conducted a study to explore how selfemployed women are coping with the balance of their dual roles as mothers and entrepreneurs in Gauteng. Despite being able to earn double income, they still bear the primary responsibility for caring for the family and ensuring their welfare. Analyzes how the structural demand for female labor affects gender differences in labor force participation. They show that gender differences in labor force participation span time and space with measures of women's labor demand.

Previous research on womens dual roles has been carried out in Indonesia, including research from Qori Kartika and Rabial Canada (2017) and Syaifuddin Zuhdi (2018). Qori Kartika and Rabial Canada's research (2017) aims to describe the perceptions of women in the city of Lahat about the concept of gender equality and gender equality (KKG) in the social and cultural sphere of society in Merapi Selatan District, Lahat Regency. The results of this study indicate that: first, the role of farmers' wives in South Merapi District, East Kalimantan is concentrated in the agricultural sector. Wives' demands to meet family needs are the same as mens', so they don't only stay at home to wait and spend their husband's income from rice fields or coffee plantations, but are also involved in earning a living through piecemeal or other means. Second, the wife's participation in improving family welfare in South Merapi District is manifested in three roles, both in the home environment,

${ }^{*}$ Corresponding author: deny.apriyadi.fis@um.ac.id 
in the economy, and in society. They have to complete all their duties as mothers and wives who are naturally responsible for helping to make a living.

Syaifuddin Zuhdi's research (2018) regarding the dual role of women in the industrial era states that basically women have a main role as someone who works in the domestic sphere. Over time, the role of women has shifted from what was originally domestic, then shifted towards the public. Several reasons that make women work in the public sector are related to the economic value in the family. The shift in the role of women into a money-oriented industrial society has an impact on family conditions and social relations in society.

This research will complement previous research regarding the dual role of women, but by raising the latest issue, namely regarding the COVID-19 pandemic which has shocked the world in recent months. This pandemic began with the coronavirus which was first discovered in Wuhan, China on December 8, 2019. On January 30, 2020, the World Health Organization (WHO) declared the corona virus a global public health emergency and on February 11, 2020, WHO stipulated the mention of the corona virus replaced as COVID-19 (Corona Virus Disease 2019). Until the announcement was made, 114 countries had reported Covid-19 cases with a total of 118,000 cases (https://nationalgeographic.grid.id/read/132059249/who-tetapkan-covid-19sebagai-pandemi-global-apa-maksudnya, 05 August 2020). There is a lot of research on the dual role of women, but it is very rare to do research on the dual role of female medical personnel. This research will highlight the dilemma of female medical personnel where they are required to provide the best service for COVID-19 patients as well as to take care of their families at home. The purpose of this study is to see the dual role of female medical personnel in the family and how it has changed since the outbreak of the COVID-19 pandemic, as well as to see the views of female medical workers on the domestic sphere which has been considered a wife's business.

\section{METHOD}

This research is a qualitative research. Qualitative research is aresearch which is based on the philosophy of positivism, is used to examine the conditions of natural objects, where the researcher as a key instrument and the results of research emphasize meaning rather than generalization (Sugiyono 2016). In qualitative research, what is used as the target of the study is the conditions of social life or society as a whole and comprehensive unit. This relates to the issues raised, namely regarding the socio-cultural problems of the community in the midst of the COVID-19 pandemic.

The data collection techniques used in this study were participatory observation, free and indepth interviews conducted via video call and/or telephone, and supported by a literature review. The process of selecting informants was taken purposively, in which the selected informants were those who understood and understood the research problem raised, so that later data would be appropriate and did not deviate far from the research topic. This research was conducted on 4-28 July 2020. The informants in this study were female medical personnel who work at hospitals that treat Covid-19 patients in the city of Surabaya. This study involved 30 informants from 15 referral and non-referral hospitals for Covid-19 in the city of Surabaya.

Analysis of the data in this study through three stages, namely making field notes, doing data reduction, and drawing conclusions. The first step carried out after the interview is to make field notes (field notes), then grouped by researchers on the basis of existing specific activities and what is being researched. At the data reduction stage, data that has gone through the grouping process will be abstracted and linked to one another. others as an integrated unit of events and facts, so as to produce strong data value. Through this abstraction, it will show the prevailing social institutions in the area or community where the research is taking place (Ahimsa-Putra 2009).

\section{RESULT AND DISCUSSION}

Role is the part that is played in every situation, and how to behave to conform to the situation (Wolfman in (Putra 2018). Soekanto (2012) states that a role determines what a person does for 
society and what opportunities the community gives him. In the past, women who worked outside the domestic sphere were often belittled because they were considered to have violated their nature. However, in an increasingly modern era, many women work outside the domestic sphere for various reasons, such as: helping to fulfill the household economy, making parents happy, social status, and so on. This is also the case for female medical personnel, where they have multiple roles in the domestic sphere and outside the domestic sphere.

The work as a medical personnel is, of course, quite tiring work. This condition will be more tiring if they return home and do all the household chores. Therefore, it is necessary to divide the tasks between husband and wife in completing household chores. This is based on considerations of time and energy efficiency. In addition, the husband's awareness is needed that his wife is tired of working to help the family economy. Based on interviews, husbands are willing to help their wives in the domestic sphere. The husband's household chores are washing clothes in the washing machine, drying clothes, watering plants, cleaning the room, and sweeping the yard. While the wife does the tasks of taking care of children, cooking, washing dishes, sweeping and mopping the floors and ironing clothes. For husband and wife who live with their family, the task is lighter because it is shared with other family members. For those who have a household assistant (ART), their duties at home are only to take care of their children and husbands.

The gender equality of the Javanese ethnic transmigration community, stated that gender roles can be seen through nurture theory and nature theory. According to the nurture theory, the differences between men and women are essentially the result of socio-cultural constructions, resulting in different roles and tasks. These differences cause women to always be left behind and neglected in their role and contribution in family life, society, nation and state. Meanwhile, according to the nature theory, the differences between women and men are natural, so they cannot change and are universal. This biological difference provides an indication and an implication that the two types have different roles and tasks. In social life, there is a division of labor, as well as in family life. This is also experienced by female medical personnel in the city of Surabaya. Even though the wife and husband both work, the socio-cultural construction that considers women to be responsible in the domestic sphere makes female medical personnel have a dual role.

Working women have a heavier role than men where men are only responsible in the public sphere, while women are responsible for the domestic and public sphere.Women carry out many tasks and assume responsibilities inside and outside the home, they must learn to use their time wisely. Conditions like this will cause gender role gaps in the family, so mutual agreement is needed in the division of roles between husbands. and wife. Based on the results of interviews, most female medical personnel share roles with their husbands in the domestic sphere. Even though in practice the role of the wife in the domestic sphere is bigger than that of the husband, at least it can reduce the gender role gap in the family.

Since the COVID-19 pandemic, medical personnel working hours have changed. The working hours change during Large-Scale Social Restriction (LSSR; PSBB in Bahasa), namely morning shift at $07.00-14.00 \mathrm{WIB}$, day shift at 14.00-19.00 WIB and night shift at 19.00-07.00 WIB. However, after the PSBB ended, working hours returned to normal. Currently, for medical personnel who work in inpatients and non-COVID-19 normal rooms, the shift division is $2 \mathrm{x}$ morning shifts, $2 \mathrm{x}$ day shifts, 2x night shifts, 2x holidays, and so on. As for medical personnel on duty in the COVID-19 room, the shift division is $1 \mathrm{x}$ morning shift, $1 \mathrm{x}$ day shift, $1 \mathrm{x}$ night shift, $1 \mathrm{x}$ holiday, and so on.

For female medical personnel who are members of the COVID-19 Team, their workload is getting heavier. They must wear complete PPE while handling patients to minimize exposure to COVID-19. This also affects the performance of medical personnel, for example inserting an IV, which is usually straightforward, but when wearing PPE, it takes a while to look for blood vessels because the glasses are often dewy. The workload of the COVID-19 team is also getting heavier because all the needs of patients in the COVID-19 isolation room must be handled by the nurse or midwife on duty. This condition affects the physical and psychological aspects of medical personnel, which then affects their domestic sphere. 
Each hospital in Surabaya City provides temporary housing facilities for medical personnel who have joined the COVID-19 team. However, not all COVID-19 teams choose to live there. HN (30 years old) revealed that when he first joined the Covid Team, HN lived in the mess that had been provided. This prevented HN from returning to her house, so that all household chores, including the affairs of her children, were handled by her husband and parents. HN will return home after 21 days in the hospital and take the SWAB test. If the result is negative, then the new HN will return home. This provoked protests from the children because they missed their mother at home. This condition lasts for 2 months. After that, $\mathrm{HN}$ decided to return home after work.

In society, of course, it is familiar to the assumption that the domestic sphere is the responsibility of the wife. Collin (Missa 2010) thinks that the family is a place of coercion, the husband as the owner and the woman as the servant. Domestic duties such as: cooking, washing dishes, sweeping, mopping, washing clothes, etc. are considered the responsibility of a wife. Meanwhile, the husband as the head of the family is responsible for fulfilling the family's needs financially. This kind of assumption is like a culture that grows and develops in Indonesian society. However, in practice, the culture that the domestic sphere is the responsibility of the wife is not fully approved by female medical personnel. Based on the results of the interview, Most of the female medical personnel consider that the roles of husband and wife in the domestic sphere are the same, so that household duties are not a burden to the wife alone. Although in practice, it is the wife who does most of the household chores.

There are two reasons why female medical personnel think that the roles of husband and wife in the domestic sphere are the same. First, the role of the wife in economic terms is balanced with the role of the husband. The wife also works to help the family economy, so that their income is sufficient to meet their daily needs and can be said to be financially secure. This then makes the position of husband and wife equal in the public sphere, so that in the domestic sphere the position of the husband must also be equal to that of the wife for a more balanced situation. This is as said by DN (26 years), a nurse from Darmo Hospital. According to DN, if a husband and wife work together, there will be more sources of income. Expenditures are borne together, so that household chores must also be done together. DN said that if a man only wants to be served without doing household chores, then he is better off not marrying any woman. This is in line with DN, YS (30 years), a midwife from Dr. Soetomo Regional Hospital, who said that a woman should be productive so that she is ready to face unexpected events, such as if one day her husband's income is no longer sufficient or if the husband experiences a reduction in income or even after being laid off, the wife could help her husband at that time. Second, the household is built together, so that all household matters are shared responsibilities. Men and women marry to build a complete household. It is impossible for a household to be built alone, without a partner. Therefore, husband and wife must help each other and cooperate in all household matters.

\section{CONCLUSION}

Female medical personnel have multiple roles, namely as wives/housewives and as medical personnel. Work in the hospital makes them have to divide their roles in the family and in the hospital. The demands of different roles put female medical personnel in a dilemma, so that many of them feel overwhelmed if they have to do both, especially during the COVID-19 pandemic. In the end, there is mutual awareness and agreement between husband and wife in carrying out their duties in the domestic sphere. The division of domestic roles between husband and wife means that the gender role gap in the family can still be well coordinated.

The view of female medical personnel regarding the cultural concept of the domestic realm is that the wife's responsibility is influenced by family factors. Those who grow up in a religious family have a different pattern of division of roles from those who grow up in an ordinary environment. For those who grew up in a religious family environment, the concept that the domestic realm is the responsibility of the wife is still upheld today. Meanwhile, those who grow up in an ordinary family environment think that the domestic sphere is a shared responsibility. 


\section{REFERENCES}

Ahimsa-Putra, H. S. (2009) 'PARADIGMA ILMU SOSIAL-BUDAYA', Kuliah Umum "Paradigma Penelitian Ilmu-ilmu Humaniora.” Bandung: Program Studi Linguistik Sekolah Pascasarjana Universitas Pendidikan Indonesia.

Aldianto, R. (2015) 'Kesetaraan gender masyarakat transmigrasi etnis Jawa', Jurnal Equilibrium Sosiologi, $3(1)$.

Arsini (2014) 'Peran Ganda Perempuan pada Keluarga Masyarakat Agraris: Kasus 10 Istri Buruh Tani di Desa Putat Purwodadi Grobogan', Sawwa.

McLellan, K.-L. and Uys, K. (2009) 'Balancing dual roles in self-employed women: An exploratory study', SA Journal of Industrial Psychology, 35(1), pp. 21-30.

Missa, L. (2010) STUDI KRIMINOLOGI PENYELESAIAN KEKERASAN DALAM RUMAH TANGGA DI WILAYAH KOTA KUPANG PROPINSI NUSA TENGGARA TIMUR, MAGISTER ILMU HUKUM.

Putra, A. (2018) 'CITRA PEREMPUAN DALAM CERITA RAKYAT WAINDHO-INDHODHIYU PADA MASYARAKAT WAKATOBI’, ETNOREFLIKA: Jurnal Sosial dan Budaya, 7(1), pp. 20-29.

Rostiyati, A. (2018) 'PERAN GANDA PEREMPUAN NELAYAN DI DESA MUARA GADING MAS LAMPUNG TIMUR', Patanjala?: Jurnal Penelitian Sejarah dan Budaya. doi: 10.30959/patanjala.v10i2.373.

Sugiyono, P. D. (2016) metode penelitian kuantitatif, kualitatif,dan R\&D, Alfabeta, $c v$.

Zuhdi, S. (2019) 'MEMBINCANG PERAN GANDA PEREMPUAN DALAM MASYARAKAT INDUSTRI', Jurnal Jurisprudence. doi: 10.23917/jurisprudence.v8i2.7327. 